\title{
УПРОВАДЖЕННЯ В ДІЯЛЬНІСТЬ ОРГАНІВ ДОСУДОВОГО РОЗСЛІДУВАННЯ УКРАЇНИ КРАЩИХ ПРАКТИК І СТАНДАРТІВ ЄВРОПЕЙСЬКОГО СОЮЗУ В ГАЛУЗІ ВИЯВЛЕННЯ, РОЗШУКУ ТА УПРАВЛІННЯ АКТИВАМИ, ОДЕРЖАВНИМИ ВІД КОРУПЦИИНИХ ТА ІНШИХ ЗЛОЧИНІВ
}

\author{
Білоус В. В.
}

\section{ВСТУП}

15 липня 2019 р. слідчими Територіального управління Державного бюро розслідувань, розташованого в місті Києві, затримано оперативного співробітника одного 3 територіальних управлінь поліції Головного управління (далі - ГУ) Національної поліції в місті Києві, який вимагав та отримав неправомірну вигоду в сумі 1000 доларів Сполучених Штатів Америки (далі - США) за повернення майна, раніше вилученого працівниками поліції ${ }^{1}$.

Невдовзі слідчі цього ж органу досудового розслідування повідомили про підозру слідчому підрозділу територіального відділу Національної поліції в Київській області у викраденні зі службового кабінету речових доказів 5000 доларів США та 3200 грн, які були вилучені його колегою під час проведення слідчих (розшукових) дій у кримінальному провадженні ${ }^{2}$.

25 липня 2019 р. детективи Національного антикорупційного бюро України спільно із працівниками Департаменту внутрішньої безпеки Національної поліції під процесуальним керівництвом прокурорів Спеціалізованої антикорупційної прокуратури викрили чотирьох осіб, причетних до незаконного заволодіння великою партією тютюнових виробів, раніше вилучених із незаконного обігу. Ідеться про колишнього начальника ГУ Нацполіції в Одеській області (з вересня 2016 по квітень 2019 рр.), його колишнього першого заступника та двох керівників приватних компаній. Слідством установлено, що керівники суб'єктів господарювання у змові з екскерівниками Нацполіції (далі - НП) Одещини у 2017 р. незаконно заволоділи великою партією контрафактної тютюнової продукції, яка мала статус речових доказів у кримінальному провадженні, що розслідували слідчі ГУ НП в Одеській області. Після цього партію цигарок, ринкова вартість якої на чорному ринку може сягати 50 млн грн,

\footnotetext{
${ }^{1}$ У Києві затримано оперуповноваженого під час отримання 1000 доларів США за повернення конфіскованого мотоцикла. Державне бюро розслідувань. 2019, 15 липня. URL: https://dbr.gov.ua.

${ }^{2}$ Слідчого поліції підозрюють у викраденні 5000 доларів США речових доказів. Державне бюро розслідувань. 2019, 29 липня. URL: https://dbr.gov.ua.
} 
випустили в незаконний обіг ${ }^{3}$. Більшу частину було вивезено за кордон, решта продавалася в Україні через інтернет-магазини, чим було завдано збитків на суму 13464280 грн. ${ }^{4}$

19-20 лютого 2020 р. слідчі територіального управління ДБР, розташованого у м. Хмельницькому, під процесуальним керівництвом прокуратури Рівненської області та за оперативного супроводу Рівненського управління ДВБ Нацполіції провели понад 30 обшуків у службових приміщеннях ГУ Нацполіції в Рівненській області та за місцем проживання осіб, які можуть бути причетні до перевищення влади або службових повноважень працівниками правоохоронного органу та службової недбалості, які спричинила тяжкі наслідки (ч. 3 ст. 365 та ч. 2 ст. 367 Кримінального кодексу (далі - КК) України). За попередньою інформацією, працівники ГУ Нацполіції в Рівненській області привласнювали автомобілі, які перебували на спеціальних майданчиках для зберігання тимчасово затриманих транспортних засобів та визнаних речовими доказами у кримінальних провадженнях, 3 метою подальшого продажу. Орієнтовна вартість зниклих авто становить понад 7 млн грн. ${ }^{5}$

13 березня 2020 р. за процесуального керівництва Офісу Генерального прокурора спільно 3 Нацполіцією припинено діяльність злочинної організації, причетної до незаконного заволодіння транспортними засобами. За версією слідства, члени вказаної злочинної організації на території м. Києва та низки областей України реалізували схему незаконного заволодіння транспортними засобами, які вилучалися державними виконавцями або слідчими та перебували на штрафмайданчиках. Заволодіння, імовірно, учинялося шляхом виготовлення та використання підроблених документів, зокрема працівниками виконавчої служби, а згодом і службовими особами сервісних центрів, що давало можливість новим власникам легально користуватись транспортними засобами. Нині встановлено 25 фактів заволодіння транспортними засобами на загальну суму понад 5 млн грн. У вказаному кримінальному провадженні здійснюється досудове розслідування за ч. 1 ст. 255 , ч. 4 ст. 28 , ч. 3 ст. 289 , ч. ч. 3,4 ст. 358 , ч. 4 ст. 190 , ч. 3 ст. 362 КК України. Уживаються заходи щодо встановлення всіх учасників угруповання, епізодів злочинної діяльності, а також викраденого майна ${ }^{6}$.

\footnotetext{
${ }^{3}$ На корупції викрито екскерівників Нацполіції Одещини. Національне антикорупціийне бюро України. 2019, 25 липня. URL: https://nabu.gov.ua.

${ }^{4}$ У суді розкрили деталі справи ексшефа поліції Одещини: двоє фігурантів уже втекли. Украӥнська правда. 2019, 26 липня. URL: https://www.pravda.com.ua.

5 Зникнення авто зі спецмайданчиків на понад 7 млн грн - ДБР провело обшуки в управлінні поліції. Державне бюро розслідувань. 2020, 21 лютого. URL: https://dbr.gov.ua.

${ }^{6}$ Правоохоронці припинили діяльність злочинної організації, члени якої підозрюються у незаконному заволодінні транспортними засобами зі штрафмайданчиків. Офіс Генерального прокурора. 2020,17 березня. URL: https://www.gp.gov.ua.
} 
Колишній суддя за пособництва адвоката та у змові зі слідчим одного 3 відділень поліції на Житомирщині вимагали від особи 1100 доларів США за повернення вилучених правоохоронцями автомобіля, мотопомпи й обладнання для незаконного видобутку бурштинуำ.

Співробітники Корабельного відділу поліції ГУ Нацполіції в Миколаївській області привласнили частину з 544 одиниць електронного обладнання для майнінгу криптовалют, вилученого під час розслідування ними крадіжки електричної енергії, яке згодом, під час обшуку, було виявлено в помешканні одного з них ${ }^{8}$.

Суддя одного з районних судів м. Одеси з порушенням територіальної підсудності ухвалив рішення про скасування арешту, накладеного у кримінальному провадженні за фактом незаконного видобутку піску в заповідних зонах Чорного моря біля узбережжя Криму на судно як забезпечення відшкодування збитків, які, згідно з висновком експерта, перевищили 140 млн грн. ${ }^{9}$

Наведений перелік покликаний продемонструвати розмаїття прецендентів і не $є$ вичерпним. Можливість учинення на систематичній основі таких і подібних їм кримінальних правопорушень щодо чужого майна посадовими особами різних органів державної влади різних рівнів у різних регіонах країни зумовлена щироким переліком чинників. Однак, на наше переконання, чи не головним із них $€$ ганебно низький рівень застосування органами досудового розслідування прогресивних законодавчих новацій та правових інститутів, породжених імплементацією до національного законодавства України кращих практик та стандартів Європейського Союзу в галузі управління арештованим майном.

\section{1. Законодавчі підвалини заснування й діяльності Національного агентства України 3 питань виявлення, розшуку та управління активами, одержаними від корупційних} та інших злочинів

У ст. 31 Конвенції Організації Об'єднаних Націй проти корупції, ратифікованої Законом України від 18 жовтня 2006 р. № 251-V, передбачено зобов'язання держав-учасниць уживати таких законодавчих та інших заходів, які можуть бути необхідними для управління

1100 доларів США за повернення обладнання для незаконного видобутку бурштину - ДБР завершило досудове розслідування відносно екссудді. Державне бюро розслідувань. 2020, 28 квітня. URL: https://dbr.gov.ua.

8 ДБР розслідує побиття поліцейськими громадянина та заволодіння обладнанням для майнінгу криптовалюти. Державне бюро розслідувань. 2020, 13 травня. URL: https://dbr.gov.ua.

9 Прокуратура розпочала кримінальне провадження за фактом винесення суддею завідомо неправосудного рішення щодо зняття арешту із судна. Офіс Генерального прокурора. 2020, 14 травня. URL: https://www.gp.gov.ua. 
компетентними органами замороженим і арештованим майном. Згідно 3 рішенням Ради Європейського Союзу (далі - СС) № 2007/845/JHA від 6 грудня 2007 р. про співробітництво між агентствами держав-членів із повернення активів у сфері виявлення і розшуку доходів, отриманих злочинним шляхом, або іншого майна, пов'язаного зі злочинною діяльністю, усі держави-учасниці СС заснували офіси з питань розшуку та повернення активів, на які може бути накладено арешт у кримінальному провадженні, або надали аналогічні повноваження існуючим органам. Директивою СС від 3 квітня 2014 р. № 2014/42/EU про арешт та конфіскацію предметів злочинної діяльності та доходів від неї в СС передбачено необхідність ужиття заходів 3 ефективного розпорядження активами, на які накладено арешт, а також створення спеціальних інституцій, відповідальних за менеджмент таких активів? із метою їх збереження або збереження їхньої вартості.

Заходом з імплементації в законодавство України рішення Ради СС № 2007/845/JНА від 6 грудня 2007 р., Директиви СС від 3 квітня 2014 р. № 2014/42/EU, а також одним 3 основних критеріїв виконання Україною Плану дій із лібералізації візового режиму з СС і виконання положень Закону України «Про засади державної антикорупційної політики (Антикорупційна стратегія)» на 2014-2017 рр. та Державної програми щодо реалізації засад державної антикорупційної політики в Україні (Антикорупційна стратегія) на 2015-2017 pp. стало створення i забезпечення належного функціонування Національного агентства України 3 питань виявлення, розшуку та управління активами, одержаними від корупційних та інших злочинів (далі - Національне агентство, АРМА).

Національне агентство створено 3 метою виконання міжнародних договорів, стороною яких є Україна. Зокрема, Конвенції про відмивання, пошук, арешт та конфіскацію доходів, одержаних злочинним шляхом; Конвенції Організації Об'єднаних Націй проти корупції; Кримінальної конвенції про боротьбу 3 корупцією; Конвенції Ради Європи про відмивання, пошук, арешт та конфіскацію доходів, одержаних злочинним шляхом, та про фінансування тероризму; 38 рекомендацій Міжнародної групи із протидії відмиванню брудних грошей (FATF), згідно з якими державам-учасницям рекомендовано створити органи, які могли б оперативно реагувати на запити аналогічних іноземних органів щодо виявлення, заморожування, арешту та конфіскації майна, отриманого незаконним шляхом. Однією 3 умов виконання Меморандуму про взаєморозуміння між Україною, як позичальником, та $Є C$, як кредитором, щодо отримання Україною макрофінансової допомоги $Є С$ у сумі до 1,8 млрд євро (ратифіковано Законом № 538-VIII від 18 червня 2015 р.) 
також стало зобов'язання визначити установу, яка буде діяти як управління з повернення активів (п. 7 (i) р. «Урядування та прозорість») $)^{10}$.

Регламентоване Законом України «Про Національне агентство України 3 питань виявлення, розшуку та управління активами, одержаними від корупційних та інших злочинів» від 10 листопада 2015 р. № 772-VIII (далі- Закон) і постановою Кабінету Міністрів України від 24 лютого 2016 р. № 104 утворення Національного агентства постало результатом імплементації зазначеного вище законодавства СС у правове поле України та відповідає практиці й тенденціям розвитку регулювання діяльності 3 розшуку й управління активами в СС. Подібні установи вже функціонують у всіх країнах-членах Свропейського Союзу та більше ніж у 100 юрисдикціях по цілому світу.

Згідно із ч. 1 ст. 2 Закону, Національне агентство України 3 питань виявлення, розшуку та управління активами, одержаними від корупційних та інших злочинів, $\epsilon$ центральним органом виконавчої влади зі спеціальним статусом, що забезпечує формування та реалізацію державної політики у сфері виявлення та розшуку активів, на які може бути накладено арешт у кримінальному провадженні чи у справі про визнання необгрунтованими активів та їх стягнення в дохід держави, та/або 3 управління активами, на які накладено арешт у кримінальному провадженні чи у справі про визнання необгрунтованими активів та їх стягнення в дохід держави або які конфісковано у кримінальному провадженні чи стягнено за рішенням суду в дохід держави внаслідок визнання їх необгрунтованими.

Відповідно до п. 1 ч. 1 ст. 1 Закону, активи - кошти, майно, майнові й інші права, на які може бути накладено або накладено арешт у кримінальному провадженні чи у справі про визнання необгрунтованими активів та їх стягнення в дохід держави або які конфісковані за рішенням суду у кримінальному провадженні чи стягнені за рішенням суду в дохід держави внаслідок визнання їх необгрунтованими.

Синтезована нами за результатами аналізу норм різних законодавчих актів комплексна характеристика дозволяє дійти висновку про те, що Національне агентство уповноважене здійснювати управління тими активами: 1) які визнані речовими доказами у кримінальному провадженні; 2) на які накладено арешт у кримінальному провадженні (зокрема, як захід забезпечення позову - лише щодо позову, пред’явленого в інтересах держави), а також у позовному провадженні у справах про визнання необгрунтованими активів та їх стягнення в дохід держави зі

\footnotetext{
${ }^{10}$ Методичні рекомендації : Настанови з управління арештованим майном : навчально-методичне видання. Київ : Ваіте, 2019. С. 13-15.
} 
встановленням заборони користуватися такими активами; 3) накладений арешт встановлює заборону розпоряджатися та/або користуватися цими активами; 4) сума або вартість цих активів дорівнює або перевищує 200 розмірів мінімальної заробітної плати, встановленої на 1 січня відповідного року; 5) ці активи можуть бути передані Національному агентству без шкоди для кримінального провадження ${ }^{11}$.

Серед найважливіших у контексті даного дослідження функцій, виконання яких покладено на Національне агентство положеннями ч. 1 ст. 9 Закону, доцільно виокремити: здійснення заходів із виявлення, розшуку, проведення оцінки активів за зверненням слідчого, детектива, прокурора, суду (слідчого судді); організацію здійснення заходів, пов'язаних із проведенням оцінки, веденням обліку й управлінням активами; формування та ведення Єдиного державного реєстру активів, на які накладено арешт у кримінальному провадженні; надання роз'яснень, методичної та консультаційної допомоги слідчим, детективам, прокурорам i суддям із питань, пов'язаних із виявленням, розшуком, проведенням оцінки й управлінням активами.

Згідно із ч. 1 ст. 15 Закону, Національне агентство взаємодіє з органами досудового розслідування, прокуратури та суду шляхом: 1) виконання звернень слідчого, детектива, прокурора, слідчого судді, суду з питань виявлення, розшуку, проведення оцінки й управління активами, а також щодо виконання рішень іноземних компетентних органів про накладення арешту та конфіскацію активів; 2) сприяння в розшуку належних приміщень, майданчиків для зберігання активів, на які накладено арешт у кримінальному провадженні чи у справі про визнання необгрунтованими активів та їх стягнення в дохід держави i щодо яких управління не здійснюється Національним агентством; 3) надання роз'яснень, методичної та консультаційної допомоги 3 питань, пов'язаних із виявленням, розшуком, проведенням оцінки й управлінням активами.

Утворення АРМА не тільки створило нові можливості, але й породило нові обов'язки для органів досудового розслідування та прокуратури. Адже Законом до Кримінального процесуального кодексу (далі - КПК) України були внесені зміни, у результаті яких, зокрема, ч. ч. 6 і 8 було доповнено, а ч. 7 ст. 100 КПК України було викладено в новій редакції.

\footnotetext{
11 Білоус В. Щодо відповідності норм абз. 7 ч. 6 ст. 100 Кримінального процесуального кодексу України і розділу III Закону України «Про Національне агентство України з питань виявлення, розшуку та управління активами, одержаними від корупційних та інших злочинів» приписам ст. 41 Конституції України, ст. ст. 316, 317, 319 Цивільного кодексу України, ст. 17 Загальної декларації прав людини і ст. 1 Першого протоколу до Конвенції про захист прав людини і основоположних свобод. Управління арештованими активами як функиія АРМА: співвідношення норм. Київ : Трансперенсі Інтернешнл Україна, 2019. С. 65-66.
} 
Згідно із цими законодавчими новелами, речові докази вартістю понад 200 розмірів прожиткового мінімуму для працездатних осіб, якщо це можливо без шкоди для кримінального провадження, передаються за письмовою згодою власника, а в разі їі відсутності - за рішенням слідчого судді, суду Національному агентству для здійснення заходів з управління ними 3 метою забезпечення їх збереження або збереження їхньої економічної вартості, а речові докази, що не містять слідів кримінального правопорушення, у вигляді предметів, великих партій товарів, зберігання яких через громіздкість або 3 інших причин неможливо без зайвих труднощів або витрати із забезпечення спеціальних умов зберігання яких сумірні з їхньою вартістю, а також речові докази у вигляді товарів або продукції, що піддаються швидкому псуванню, такої самої вартості - для їх реалізації з урахуванням особливостей, визначених законом.

За вищеописаних обставин і тоді, коли речові докази, що не містять слідів кримінального правопорушення, у вигляді предметів, великих партій товарів, зберігання яких через громіздкість або з інших причин неможливо без зайвих труднощів або витрати із забезпечення спеціальних умов зберігання яких сумірні з їхньою вартістю, а також речові докази у вигляді товарів або продукції, що піддаються швидкому псуванню: 1) передаються за письмовою згодою власника, а в разі ії відсутності - за рішенням слідчого судді, суду для реалізації, якщо це можливо без шкоди для кримінального провадження, або 2) передаються для їх технологічної переробки чи знищуються за рішенням слідчого судді, суду, якщо вони належать до вилучених 3 обігу предметів чи товарів, а також якщо їх тривале зберігання небезпечне для життя чи здоров'я людей або довкілля, слідчий за погодженням із прокурором або прокурор звертається 3 відповідним клопотанням до слідчого судді місцевого суду, у межах територіальної юрисдикції якого здійснюється досудове розслідування, а у кримінальних провадженнях щодо злочинів, віднесених до підсудності Вищого антикорупційного суду, - до слідчого судді Вищого антикорупційного суду, або до суду під час судового провадження, яке розглядається згідно зі ст. ст. 171-173 КПК. Прокурор у випадку, передбаченому в абз. 7 ч. 6 цієї статті, не пізніше наступного робочого дня 3 моменту постановлення ухвали слідчого судді, суду надсилає копію цієї ухвали Національному агентству із зверненням щодо прийняття активів, а також уживає невідкладних заходів щодо передачі цих активів AРМА. Реалізація, технологічна переробка або знищення речових доказів у випадках, передбачених цією статтею, здійснюються в порядку, встановленому Кабінетом Міністрів України, а якщо такі речові докази 
передані Національному агентству - відповідно до закону й ухвалених на його виконання актів законодавства.

Отже, запобігання вчиненню вищеописаних злочинів визначалося належним використанням уповноваженими суб'єктами можливостей, породжених утворенням АРMА, та виконанням обов'язків, визначених КПК.

\section{2. Проблеми діяльності з виявлення, розшуку та управління активами, одержаними від корупційних та інших злочинів, i шляхи їх вирішення}

Прикметно, що в обгрунтування доводів клопотання прокурора про застосування запобіжних заходів щодо одного з підозрюваних у згаданій вище справі про незаконне заволодіння великою партією контрафактної тютюнової продукції, яка мала статус речових доказів у кримінальному провадженні, що розслідували слідчі ГУ НП в Одеській області, слідчому судді було подано недостовірну інформацію про наявність у цього підозрюваного нерухомого майна на тимчасово окупованій території ${ }^{12}$.

Щодо цього варто зазначити, що запобігання помилці й одержання та подання слідчому судді достовірної інформації в наведеному випадку визначалося належним використанням можливостей зі звернення слідчим, прокурором, органом досудового розслідування чи органом прокуратури до Національного агентства зі зверненням щодо виявлення та/або розшуку активів, на які може бути накладено арешт у кримінальному провадженні.

Адже згідно $з$ положеннями абз. 2 ч. 1 ст. 170 КПК України, слідчий, прокурор повинні вжити необхідних заходів із метою виявлення та розшуку майна, на яке може бути накладено арешт у кримінальному провадженні, зокрема шляхом витребування необхідної інформації в Національного агентства. Порядок взаємодії під час розгляду звернень органів, що здійснюють досудове розслідування, прокуратури та виконання запитів іноземних держав щодо виявлення та розшуку активів затверджено наказом Національного агентства України 3 питань виявлення, розшуку та управління активами, одержаними від корупційних та інших злочинів, Національного антикорупційного бюро України, Генеральної прокуратури України, Служби безпеки України, Міністерства внутрішніх справ України, Міністерства фінансів України від 20 жовтня 2017 р. № 115/197-о/297/586/869/857, зареєстрованим у Міністерстві юстиції України 2 листопада 2017 р. за № 1342/31210 (далі Порядок взаємодіï).

\footnotetext{
12 Суд відправив ексначальника поліції Одещини під домашній арешт. Украӥнська правда. 2019,26 липня. URL: https://www.pravda.com.ua.
} 
Доцільно наголосити на тому, що жодних обмежень за видом майна, категорією злочинів чи іншими підставами чинне законодавство України водночас не встановлює. Отже, будь-який уповноважений суб'єкт наділений правом звернутися до АРМА щодо виявлення та/або розшуку активів у будь-якому здійснюваному ним кримінальному провадженні. Однак цим, за даними Національного агентства, скористалися порівняно незначна кількість суб'єктів: у 2017 р. сукупно до АРМА надійшло 69, у 2018 р. - $1064^{13}$, у 2019 р. - 1685 звернень $^{14}$, що разюче дисонуе із загальною кількістю кримінальних проваджень, розпочатих за цей час.

Однак за результатами опрацювання навіть такої незначної кількості звернень щодо виявлення та розшуку активів тільки у 2018 р. АРМА було виявлено та розшукано активи на території України та за ії межами в такому обсязі: корпоративні права - частки у статутних капіталах компаній вартістю $21 \quad 160$ млн грн.; цінні папери вартістю 557 млн грн.; 7093 об'єкти нерухомості; 4457 земельних ділянок; 3758 транспортних засоби; 2522 одиниці іншого майна (товарів); 950 одиниць сільськогосподарської техніки; 848 фактів володіння правами на винаходи, торгові марки; грошові кошти в сумі 357,7 млн грн., 97,8 млн доларів США, 1,9 млн євро ${ }^{15}$. У 2019 р. - понад 266 тисяч одиниць майна та майнових прав, а також більше 30 млрд грн часток у статутних капіталах, понад 3,5 млрд грн у цінних паперах, а також більше мільярда грошових коштів у гривневому еквіваленті ${ }^{16}$.

Непропорційно низький рівень звернень до Національного агентства на тлі високого рівня досягнутих АРМА результатів діяльності передусім можна пояснити необізнаністю широкого загалу уповноважених суб’єктів про весь інституційний потенціал останнього. Власне і саме Національне агентство популяризує переважно управління активами ${ }^{17}$, під яким, згідно 3 п. 4 ч. 1 ст. 1 Закону, треба розуміти діяльність із володіння, користування та/або розпорядження активами, тобто забезпечення збереження активів, на які накладено арешт у кримінальному провадженні

\footnotetext{
13 Звіт про діяльність Національного агентства України з питань виявлення, розшуку та управління активами, одержаними від корупційних та інших злочинів, за 2018 р. C. 27. URL: https://arma.gov.ua/ files/general/2019/04/15/20190415170302-74.pdf.

${ }_{14}^{14}$ Відбувся публічний звіт т.в.о. Голови АРМА. Агентство з менеджменту та розиуку активів. 2020, 3 березня. URL: https://arma.gov.ua.

15 Звіт про діяльність Національного агентства України з питань виявлення, розшуку та управління активами, одержаними від корупційних та інших злочинів, за 2018 р. C. 30. URL: https://arma.gov.ua/ files/general/2019/04/15/20190415170302-74.pdf.

16 Україна увійшла до топ-5 активних країн світу по кількості запитів із повернення активів. URL: https://arma.gov.ua/news/typical/ukraina-uviyshla-do-top-5-aktivnih-krain-svitu-po-kilkosti-zapitiv-zpovernennya-aktiviv.

${ }^{17}$ Методичні рекомендації : Настанови 3 управління арештованим майном : навчально-методичне видання. Київ : Ваіте, 2019. 208 с.
} 
чи у справі про визнання необгрунтованими активів та їх стягнення в дохід держави, та їхньої економічної вартості або реалізацію таких активів чи передачу їх в управління відповідно до цього Закону, а також реалізацію активів, конфіскованих у кримінальному провадженні чи стягнених за рішенням суду в дохід держави внаслідок визнання їх необгрунтованими. Першочергово до управління активами прикута увага й відомих неурядових інституцій ${ }^{18}$. У науковій літературі піддаються аналізу окремі проблемні аспекти застосування арешту майна у кримінальному провадженні, формулюються рекомендації щодо усунення прогалин, колізій та інших юридичних дефектів чинної редакції гл. 17 Кримінального процесуального кодексу України ${ }^{19}$.

Усвідомленння диструктивності руху ув зворотному напрямі (від управління вже арештованими активами до планування діяльності, що має передувати накладенню арешту на них) спонукало АРМА до вивчення відповідного міжнародного досвіду. Результатом цього стало проведення презентації та обговорення 14 серпня 2019 р. за участі АРМА, ГПУ, НАБУ, САП та інших правоохоронних органів і відомств дослідження «Планування перед арештом активів, одержаних злочинним шляхом або використаних для вчинення злочину». Механізм планування перед арештом активів $\epsilon$ передовою практикою, яка дозволяє належно організувати подальше управління арештованими активами та забезпечити раціональне використання ресурсів держави у процесі повернення отриманих у неправомірний спосіб активів. Належне планування перед арештом дасть можливість визначити доцільність арешту активу, встановити правильні часові межі, допоможе зрозуміти, якими саме характеристиками повинен бути наділений майбутній управитель того чи іншого арештованого активу. Належне планування перед арештом відіграє важливу роль у забезпеченні збереження як власне активу, так i його економічної вартості, що є головним завданням менеджменту активів ${ }^{20}$.

Однак метою і цього дослідження не було охоплено вивчення проблем використання органами досудового розслідування можливостей, заснованих на першочергових повноваженнях Національного агентства. Це спонукає нас звернути увагу на малодосліджені можливості APMA зі здійнення дієвих заходів із виявлення та розшуку активів, що може передувати управлінню останніми. Згідно з положеннями п. п. 2 і 3 ч. 1

\footnotetext{
18 Управління арештованими активами як функція АРМА: співвідношення норм. Київ : Трансперенсі Інтернешнл Україна, 2019. 73 с.

19 Туманянц А., Медвєдєв В. Арешт майна у кримінальному провадженні: окремі проблеми застосування. Право і суспільство. 2018. Ч. 2. № 3. С. 194-199.

${ }^{20}$ Відбулася презентація концепції планування перед арештом активів. Агентство з менеджменту та розиуку активів. 2019, 16 серпня. URL: https://arma.gov.ua.
} 
ст. 1 Закону, виявлення активів - діяльність із встановлення факту існування активів, на які може бути накладено арешт у кримінальному провадженні чи у справі про визнання необгрунтованими активів та їх стягнення в дохід держави, а розшук активів -діяльність із визначення їхнього місцезнаходження.

3 метою виявлення та розшуку активів Національне агентство: 1) уживає відповідно до звернень органів, що здійснюють досудове розслідування, прокуратури, судів заходи для виявлення та розшуку активів, взаємодіє із цими органами з метою накладення арешту на такі активи та їх конфіскації чи їх стягнення в дохід держави внаслідок визнання необгрунтованими активів; 2) здійснює міжнародне співробітництво з відповідними органами іноземних держав у частині обміну досвідом та інформацією з питань, пов'язаних iз виявленням, розшуком та управлінням активами; 3) забезпечує співробітництво 3 міжнародними, міжурядовими організаціями, мережами, діяльність яких спрямована на забезпечення міжнародного співробітництва у сфері виявлення, розшуку й управління активами, зокрема 3 Камденською міжвідомчою мережею 3 питань повернення активів (CARIN), представляє Україну в цій організації. 3 метою виконання вищезазначених завдань Національне агентство має право отримувати, обробляти та здійснювати обмін інформацією про фізичних та юридичних осіб у порядку, визначеному міжнародними договорами та законодавством України (ст. 16 Закону). АРМА забезпечує виконання звернень органів досудового розслідування, прокуратури та судів щодо виявлення, розшуку активів та надає відповідь у найкоротший можливий строк, але не пізніше ніж протягом трьох робочих днів із дня надходження звернення, або в інший більш тривалий строк, зазначений у ньому. Цей строк може бути продовжений за погодженням з органом досудового розслідування, прокуратури та судом (ст. 17 Закону).

У сфері виявлення та розшуку активів Закон надає АРМА повноваження щодо отримання доступу до всіх реєстрів та інформаційних банків даних, розпорядниками та/або володільцями яких є державні органи й органи місцевого самоврядування, а уповноважені особи АРМА мають право витребовувати в цих органів документи, які можуть сприяти процесу виявлення та розшуку активів. Крім цього, Положенням про Національне агенство, завердженим постановою Кабінету Міністрів України від 11 липня 2018 р. № 613, визначено, що АРМА для виконання своїх завдань може також одержувати й обробляти інформацію стосовно фізичних та юридичних осіб, а також здійснювати обмін такою інформацією 3 органами іноземних держав, державними органами, органами місцевого самоврядування, підприємствами, установами й організаціями незалежно 
від форми власності, зокрема з банками, депозитарними та фінансовими установами, приватними виконавцями, аудиторами, нотаріусами, оцінювачами, а також експертами, арбітражними керуючими, членами ліквідаційних комісій, ліквідаторами, уповноваженими особами Фонду гарантування вкладів фізичних осіб (зокрема, копії документів). АРМА має безоплатний доступ до інформації, що $є$ у володінні державних органів (органів місцевого самоврядування). Національним агентством досягнуто значного прогресу 3 реалізації вказаних положень законодавства на практиці, а тому на підставі укладених меморандумів та угод, ухвалених спільних рішень натепер АРМА має доступ до багатьох реєстрів та інформаційних баз даних, володільцями та/або розпорядниками яких $\epsilon$ державні органи й органи місцевого самоврядування. Лише перелік цих інформаційних ресурсів займає не одну сторінку.

Зазначимо, що доступ для інших користувачів до відповідних джерел закритий або суттєво обмежений. Водночас отримання інформації (фінансової також) із зазначених реєстрів та баз даних здійснюється АРМА без необхідності винесення судових ухвал, що $є$ одним із найбільш важливих індикаторів ефективності Національного агентства. Група авторитетних експертів міжнародного рівня у відповідній сфері, сформована за сприяння Антикорупційної ініціативи ЄС в Україні, надаючи технічну оцінку роботи АРМА, дійшла висновку про те, що рівень та легкість доступу Національного агентства до наявних баз даних, реєстрів та фінансової інформації без судового наказу є кращим, ніж у багатьох з офісів ARO у країнах СC, та відображає санкціоноване право доступу до багатьох підрозділів фінансової розвідки ${ }^{21}$.

Крім безпосереднього доступу до інформаційних джерел даних державних органів, банківських установ, АРМА здійснює аналіз відкритих джерел даних (OSINT), як в Україні, так і за їі межами, а також отримує доступи до платних баз даних. АРМА продовжує вдосконалюватись у роботі з відкритою та закритою частинами мережі Інтернет зокрема, Dark web), використовує інформацію із соціальних мереж, засобів масової інформації, журналістську інформацію й іншу публічно доступну інформацію з відкритих джерел для виявлення та розшуку активів ${ }^{22}$.

АРМА на постійній основі здійснюється робота 3 пошуку й аналізу нових банків даних, що можуть бути використані для виявлення або

\footnotetext{
21 Звіт про діяльність Національного агентства України з питань виявлення, розшуку та управління активами, одержаними від корупційних та інших злочинів, за 2018 p. C. 19. URL: https://arma.gov.ua/files/general/2019/04/15/20190415170302-74.pdf.

22 Звіт про діяльність Національного агентства України з питань виявлення, розшуку та управління активами, одержаними від корупційних та інших злочинів, за 2018 p. C. 22. URL: https://arma.gov.ua/files/general/2019/04/15/20190415170302-74.pdf.
} 
розшуку активів. У результаті цієї роботи АРМА було визначено понад 300 реєстрів, баз даних, інформаційних і аналітичних джерел, що можуть використовуватись під час виконання завдань АРМА. Проаналізовані джерела інформації поділяються на такі, що є у відкритому доступі, й ті, доступ до яких закрито (обмежено). Доступ до таких джерел може бути безкоштовним, а може забезпечуватись на платній основі. Частину баз даних та реєстрів адмініструють державні органи (органи місцевого самоврядування), іншу частину - підприємства, що підпорядковані державним органам, певні масиви інформації перебувають у розпорядженні інших суб'єктів господарювання, зокрема й в інших юрисдикціях. Отже, робота Національного агентства із приєднання до джерел інформації, необхідних для здійснення розшуку та виявлення активів, має системний триваючий характер.

АРМА також здійснює міжнародне співробітництво 3 органами іноземних держав, до компетенції яких належать питання виявлення, розшуку й управління активами, іншими компетентними органами іноземних держав, відповідними міжнародними організаціями, міжурядовими організаціями, ініціативами, мережами, діяльність яких спрямована на забезпечення міжнародного співробітництва у сфері виявлення, розшуку й управління активами, зокрема 3: Камденською міжвідомчою мережею з питань повернення активів (CARIN), Ініціативою 3 повернення викрадених активів (StAR), Глобальною ініціативою контактних пунктів Інтерполу (Interpol Global Focal Point Initiative), представляс Україну в зазначених організаціях, ініціативах, мережах та забезпечує виконання запитів відповідних органів іноземної держави або компетентних органів, визначених законодавством, щодо міжнародного співробітництва у сфері виявлення та розшуку активів відповідно до міжнародних договорів України або за принципом взаємності ${ }^{23}$. Завдяки діяльності AРМА у сфері виявлення і розшуку активів Україна вслід за Іспанією, Францією та Швейцарією у 2019 р. увійшла до першої п’ятірки найбільш активних країн світу 3 найбільшою кількістю міжнародних запитів через мережу з повернення активів ${ }^{24}$.

Чи спроможний здійснювати такий обсяг діяльності фізично та за наявних повноважень окремо взятий суб'єкт звернення - слідчий, детектив, прокурор, орган досудового розслідування чи орган прокуратури? Питання риторичне. Отже, саме АРМА сьогодні може

\footnotetext{
23 Звіт про діяльність Національного агентства України з питань виявлення, розшуку та управління активами, одержаними від корупційних та інших злочинів, за 2018 p. C. 23. URL: https://arma.gov.ua/files/general/2019/04/15/20190415170302-74.pdf.

24 Україна увійшла до топ-5 активних країн світу по кількості запитів 3 повернення активів. Агентство з менеджменту та розиуку активів. 2020, 20 лютого. URL: https://arma.gov.ua.
} 
слугувати для органів досудового розслідування тим унікальним інформаційним хабом, повсякчасне звернення до якого здатне істотно покращити рівень розкриття та розслідування злочинів. На нашу думку, саме через це нормою абз. 2 ч. 1 ст. 170 КПК, якою на слідчого, прокурора покладено обов'язок ужити необхідних заходів із метою виявлення та розшуку майна, на яке може бути накладено арешт у кримінальному провадженні, як інноваційний та релевантний інформаційній ері спосіб визначено витребування необхідної інформації в Національного агентства. Проте цією нормою визначено обмежену мету виявлення та розшуку майна - накладення на нього арешту у кримінальному провадженні.

Відповідно до ч. ч. 1, 2 ст. 170 КПК, арештом майна є тимчасове, до скасування у встановленому цим Кодексом порядку, позбавлення за ухвалою слідчого судді або суду права на відчуження, розпорядження та/або користування майном, щодо якого існує сукупність підстав чи розумних підозр уважати, що воно є доказом злочину, підлягає спеціальній конфіскації в підозрюваного, обвинуваченого, засудженого, третіх осіб, конфіскації в юридичної особи, для забезпечення цивільного позову, стягнення 3 юридичної особи отриманої неправомірної вигоди, можливої конфіскації майна.

Завданням арешту майна є запобігання можливості його приховування, пошкодження, псування, зникнення, втрати, знищення, використання, перетворення, пересування, передачі, відчуження. Арешт майна допускається 3 метою забезпечення: 1) збереження речових доказів; 2) спеціальної конфіскації; 3) конфіскації майна як виду покарання або заходу кримінально-правового характеру щодо юридичної особи; 4) відшкодування збитків, завданих унаслідок кримінального правопорушення (цивільний позов), чи стягнення з юридичної особи отриманої неправомірної вигоди.

На наше переконання, сучасний потенціал та ресурсна база APMA 3 виявлення (встановлення факту існування) та розшуку (визначення місцезнаходження) активів $\epsilon$ надзвичайно затребуваними органами досудового розслідування не тільки для накладення арешту на майно у кримінальному провадженні. Раціональне використання інституційних спроможностей Національного агентства може слугувати збиранню доказів у кримінальному провадженні загалом та досягненню цілей окремих слідчих (розшукових) дій зокрема. Особливо виявленню та розшуку об'єкта обшуку, де обшукуваним може бути приховано об'єкт пошуку чи може переховуватися останній.

Так, відповідно до ч. 2 ст. 93 КПК, сторона обвинувачення здійснює збирання доказів шляхом проведення слідчих (розшукових) дій та 
негласних слідчих (розшукових) дій, витребування й отримання від органів державної влади, органів місцевого самоврядування, підприємств, установ та організацій, службових та фізичних осіб речей, документів, відомостей, висновків експертів, висновків ревізій і актів перевірок, проведення інших процесуальних дій, передбачених цим Кодексом. Відомості, одержані від АРМА, можуть становити інформаційну основу для результативного планування й проведення слідчих (розшукових) дій та негласних слідчих (розшукових) дій.

Наприклад, цілями обшуку є: 1) виявлення та фіксація відомостей про обставини вчинення кримінального правопорушення; 2) відшукання знарядь кримінального правопорушення або майна, яке було здобуте в результаті його вчинення; 3) встановлення місцезнаходження розшукуваних осіб (ч. 1 ст. 234 КПК). А обстеження публічно недоступних місць, житла чи іншого володіння особи шляхом таємного проникнення в них, зокрема 3 використанням технічних засобів, може здійснюватися 3 метою: 1) виявлення і фіксації слідів учинення тяжкого або особливо тяжкого злочину, речей і документів, що мають значення для їх досудового розслідування; 2) виготовлення копій чи зразків зазначених речей i документів; 3) виявлення та вилучення зразків для дослідження під час досудового розслідування тяжкого або особливо тяжкого злочину; 4) виявлення осіб, які розшукуються; 5) встановлення технічних засобів аудіо-, відеоконтролю особи (ч. 1 ст. 267 КПК).

Отже, інформація АРМА про виявлене та розшукане майно може водночас слугувати досягненню органами досудового розслідування широкого спектра правомірних цілей (установлення місцезнаходження та виявлення розшукуваних осіб; відшукання слідів і знарядь кримінального правопорушення або майна, яке було здобуте в результаті його вчинення тощо), не обмежуючись суто метою накладення арешту у кримінальному провадженні. Як за досягнення цієї мети, так і у згаданих та багатьох інших подібних випадках важливе встановлення конкретного місця (місць), проведення відповідної процесуальної дії, у якому можна забезпечити досягнення визначеної законом мети. Водночас, як наголошується в Довіднику з повернення активів, виданому Ініціативою 3 повернення вкрадених активів (StAR) Світового банку й УН3, скоординований iз фахівцями 3 управління активами обшук може слугувати найкращим моментом для вилучення активів. Особливо тих, що потребують визначення місця зберігання, безпечного переміщення активів до цього місця. Про необхідність завчасних консультацій між правоохоронцями та фахівцями, які працюють над поверненням активів, ідеться і у визначенні стратегії щодо найбільш оптимального моменту для 
накладення арешту. Наголошується на тому, що передчасне накладення арешту може розкрити інформацію про розслідування, тоді як запізніле застосування арешту може призвести до втрати активів або ускладнити встановлення їхнього місцезнаходження ${ }^{25}$.

Під час обговорення концепції планування перед арештом активів, одержаних злочинним шляхом або використаних для вчинення злочину, та можливих механізмів імплементації в національне правове поле учасники дискусії - представники АРМА, ГПУ, НАБУ, САП та інших правоохоронних органів і відомств дійшли висновків про те, що інструмент планування перед арештом активів потребує законодавчого закріплення, злагоджених дій та довіри між органами досудового розслідування, прокурорами й АРМА.

Водночас до запровадження чіткого законодавчого регулювання інструменту планування перед арештом активів ${ }^{26}$ сьогодні вже існує можливість його імплементації та застосування в рамках чинного законодавства. Так, планування перед арештом активів може здійснюватися в рамках функції АРМА з надання роз'яснень, методичної та консультаційної допомоги слідчим, детективам, прокурорам і суддям із питань, пов'язаних із виявленням, розшуком, проведенням оцінки й управлінням активами, а також функції зі здійснення заходів із виявлення, розшуку, проведення оцінки активів за зверненням слідчого, детектива, прокурора, суду (слідчого судді) ${ }^{27}$.

\section{ВИСНОВКИ}

Часи успішного розслідування злочинів суто завдяки майстерності слідчого й оперуванню індуктивним методом (сходженням від окремого до загального) давно відійшли в минуле. Орієнтація сучасної криміналістичної діяльності на комплексне вирішення інституційних завдань досудового розслідування в умовах тотальної діджиталізації всіх сфер життєдіяльності глобалізованого світу слугує підставою для формулювання нами рекомендацій щодо розроблення належного теоретичного i нормативно-правового забезпечення й утілення в повсякчасну практику алгоритму взаємодії органів досудового розслідування 3 Національним агентством, ключовими етапами якої повинні стати:

\footnotetext{
25 Assert Recovery Handbook A Guide for Practitioners / Jean-Pierre Brun et al. P. 79-85. URL: https://star.worldbank.org/sites/star/files/asset_recovery_handbook_0.pdf.

26 Сигидин В. Яких законодавчих змін потребує APMA. Цензор.нет. 2020, 14 квітня. URL: https://mbiz.censor.net.ua.

${ }_{27}$ Відбулася презентація концепції планування перед арештом активів. Агентство з менеджменту та розиуку активів. 2019, 16 серпня. URL: https://arma.gov.ua.
} 
1) звернення слідчого, детектива, прокурора, органу досудового розслідування чи органу прокуратури, зокрема за клопотанням захисника, потерпілого чи цивільного позивача, до Національного агентства зі зверненням щодо виявлення та/або розшуку активів, на які може бути накладено арешт у кримінальному провадженні, та надання копій документів та інших матеріалів, якими слідчий, прокурор обгрунтовуватиме доводи клопотання про арешт цього майна;

2) звернення АРМА до органів досудового розслідування, прокуратури iз запитом щодо надання інформації, необхідної для надання Національним агентством відповіді на запит відповідного органу іноземної держави, уповноваженого нею на виконання функцій установи 3 повернення активів;

3) звернення Національного агентства 3 висновком (інформація АРМА про ознаки кримінальних правопорушень, які виявлені під час виконання визначених законом функцій та повноважень Національного агентства та не вказані у зверненні) до органу досудового розслідування, до підслідності слідчих, детективів якого належить розслідування кримінального правопорушення, ознаки якого викладені у висновку;

4) планування розслідування злочинів (особливо корупційної спрямованості) на основі інформації АРМА про ознаки кримінальних правопорушень, які виявлені під час виконання визначених законом функцій та повноважень Національного агентства, у контексті осіб, яким прямо чи опосередковано можуть належати активи, що можуть бути арештовані $з$ метою забезпечення кримінального провадження, а також близьких осіб таких осіб та/або третіх осіб, що можуть бути пов'язані 3 такими особами;

5) планування відповідних слідчих (розшукових) дій та негласних слідчих (розшукових) дій на основі відомостей, що містяться у відповіді Національного агентства (документ, складений за результатами опрацювання звернення), зокрема із залученням уповноважених осіб APMA;

6) залучення уповноважених осіб Національного агентства як спеціалістів до участі у проведенні відповідних слідчих (розшукових) дій та фіксуванні їх результатів ${ }^{28}$, необхідних для приймання/передачі активів в управління, формування та ведення Єдиного державного реєстру активів,

\footnotetext{
${ }^{28}$ Білоус В. Особливості застосування спеціальних знань при поводженні з активами, на які може бути накладено арешт у кримінальному провадженні. Particularitătile adaptării legislaţiei Republicii Moldova și Ucrainei la legislația Uniunii Europene : materiale ale Conferinței Ştiințifice şi Practice Internaționale, 23-24 martie, 2018 / com. org. : V. Bujor (președinte) et al. Chişinău : Lulian ; Tipogr. Cetatea de Sus, 2018. 360 p. P. 300-303.
} 
на які накладено арешт у кримінальному провадженні, й ефективного управління арештованими активами;

7) залучення уповноважених осіб Національного агентства як спеціалістів до обгрунтування клопотанням про арешт майна й оформлення матеріалів, що мають значення для вирішення питання про арешт майна;

8) залучення уповноважених осіб Національного агентства як свідків до розгляду клопотання про арешт майна слідчим суддею;

9) передача арештованих активів відповідно до ст. 100 КПК України АРМА для здійснення заходів з управління ними 3 метою забезпечення їх збереження або збереження їхньої економічної вартості чи реалізації 3 урахуванням особливостей, визначених законом.

Посилення ефекту такої взаємодії потребує невідкладного перегляду тактики проведення окремих слідчих (розшукових) дій i загальної методики розслідування злочинів 3 подальшим удосконаленням програм професійної підготовки майбутніх правників та підвищення кваліфікації слідчих, детективів, прокурорів, суддів і адвокатів, що практикують.

\section{АНОТАЦІЯ}

Стаття присвячена дослідженню проблем упровадження в діяльність органів досудового розслідування України кращих практик і стандартів Європейського Союзу в галузі виявлення, розшуку й управління активами, одержаними від корупційних та інших злочинів. Ацентовано увагу на зловживаннях, що мають місце в цій царині, та пошуку шляхів запобігання їм. Проаналізовано нормативно-провові підвалини створення та функціонування Національного агентства України з питань виявлення, розшуку та управління активами, одержаними від корупційних та інших злочинів (АРМА). Роглянуто результати діяльності Національного агентства у 2017-2020 роках та його інституційний потенціал крізь призму використання останнього 3 метою задоволення нагальних потреб органів досудового розслідування. Виявлено дисбаланс у співпраці останніх 3 Національним агенством на користь управління вже арештованим майном за недостатнього рівня взаємодії в галузі виявлення та розшуку активів, на які може бути накладено арешт у кримінальному провадженні. Запропоновано розглядати Національне агентство України 3 питань виявлення, розшуку та управління активами, одержаними від корупційних та інших злочинів, як унікальний інформаційний хаб, повсякчасне звернення до якого здатне істотно покращити рівень розкриття та розслідування злочинів. Розроблено криміналістичні рекомендації щодо втілення в щоденну практику доцільного алгоритму взаємодії органів 
досудового розслідування з Національним агентством в рамках не тільки планування і здійснення окремих процесуальних дій, але й діяльності 3 розслідування злочинів загалом. Виходячи із цього, наголошено на необхідності невідкладного перегляду тактики проведення окремих слідчих (розшукових) дій і загальної методики розслідування злочинів 3 подальшим удосконаленням програм професійної підготовки майбутніх правників та підвищення кваліфікації слідчих, детективів, прокурорів, суддів і адвокатів, що практикують.

\section{ЛІТЕРАТУРА}

1.У Києві затримано оперуповноваженого під час отримання 1000 доларів США за повернення конфіскованого мотоцикла. Державне бюро розслідувань. 2019, 15 липня. URL: https://dbr.gov.ua.

2. Слідчого поліції підозрюють у викраденні 5000 доларів США речових доказів. Державне бюро розслідувань. 2019, 29 липня. URL: https://dbr.gov.ua.

3. На корупції викрито екскерівників Нацполіції Одещини. Національне антикорупщійне бюро Украӥни. 2019, 25 липня. URL: https://nabu.gov.ua.

4. У суді розкрили деталі справи екс-шефа поліції Одещини: двоє фігурантів уже втекли. Украӥнська правда. 2019, 26 липня. URL: https://www.pravda.com.ua.

5. Зникнення авто зі спецмайданчиків на понад 7 млн грн - ДБР провело обшуки в управлінні поліції. Державне бюро розслідувань. 2020, 21 лютого. URL: https://dbr.gov.ua.

6. Правоохоронці припинили діяльність злочинної організації, члени якої підозрюються у незаконному заволодінні транспортними засобами зі штрафмайданчиків. Офіс Генерального прокурора. 2020, 17 березня. URL: https://www.gp.gov.ua.

7. 1100 доларів США за повернення обладнання для незаконного видобутку бурштину - ДБР завершило досудове розслідування відносно екссудді. Державне бюро розслідувань. 2020, 28 квітня. URL: https://dbr.gov.ua.

8. ДБР розслідує побиття поліцейськими громадянина та заволодіння обладнанням для майнінгу криптовалюти. Державне бюро розслідувань. 2020, 13 травня. URL: https://dbr.gov.ua.

9. Прокуратура розпочала кримінальне провадження за фактом винесення суддею завідомо неправосудного рішення щодо зняття арешту 3 судна. Офіс Генерального прокурора. 2020, 14 травня. URL: https://www.gp.gov.ua. 
10. Методичні рекомендації : Настанови з управління арештованим майном : навчально-методичне видання. Київ : Ваіте, 2019. 208 с.

11. Білоус В. Щодо відповідності норм абз. 7 ч. 6 ст. 100 Кримінального процесуального кодексу України і розділу III Закону України «Про Національне агентство України з питань виявлення, розшуку та управління активами, одержаними від корупційних та інших злочинів» приписам ст. 41 Конституції України, ст. ст. 316, 317, 319 Цивільного кодексу України, ст. 17 Загальної декларації прав людини і ст. 1 Першого протоколу до Конвенції про захист прав людини і основоположних свобод. Управління арештованими активами як функиія АРМА : співвідношення норм. Київ : Трансперенсі Інтернешнл Україна, 2019. С. 63-70.

12. Суд відправив екс-начальника поліції Одещини під домашній арешт. Украӥнська правда. 2019, 26 липня. URL: https://www.pravda.com.ua.

13. Звіт про діяльність Національного агентства України 3 питань виявлення, розшуку та управління активами, одержаними від корупційних та інших злочинів, за 2018 p. URL: https://arma.gov.ua/files/ general/2019/04/15/20190415170302-74.pdf.

14. Відбувся публічний звіт т.в.о. Голови АРМА. Агентство 3 менеджменту та розшуку активів. 2020, 3 березня. URL: https://arma.gov.ua.

15. Україна увійшла до топ-5 активних країн світу по кількості запитів 3 повернення активів. Агентство з менеджменту та розшуку активів. 2020, 20 лютого. URL: https://arma.gov.ua.

16. Управління арештованими активами як функція APMA: співвідношення норм. Київ : Трансперенсі Інтернешнл Україна, 2019. 73 с.

17. Відбулася презентація концепції планування перед арештом активів. Агентство з менеджменту та розиуку активів. 2019, 16 серпня. URL: https://arma.gov.ua.

18. Туманянц А., Медвєдєв В. Арешт майна у кримінальному провадженні: окремі проблеми застосування. Право і суспільство. 2018. Ч. 2. № 3. С. 194-199.

19. Assert Recovery Handbook A Guide for Practitioners / Jean-Pierre Brun et al. URL: https://star.worldbank.org/sites/star/files/asset_recovery_handbook_ $0 . p d f$.

20. Сигидин В. Яких законодавчих змін потребує АРМА. Цензор.нет. 2020, 14 квітня. URL: https://mbiz.censor.net.ua.

21. Білоус В. Особливості застосування спеціальних знань при поводженні 3 активами, на які може бути накладено арешт у кримінальному провадженні. Particularitătile adaptării legislaţiei Republicii Moldova și Ucrainei la legislația Uniunii Europene : materiale ale Conferinței 
Științifice și Practice Internaţionale, 23-24 martie, 2018 / com. org. : V. Bujor (președinte) et al. Chişinău : Lulian ; Tipogr. Cetatea de Sus, 2018. 360 p. P. 300-303.

Information about author:

Bilous V. V.,

Ph. D.,

Associate Professor of the Criminalistics Department

Yaroslav Mudryi National Law University

77, Pushkinska str., Kharkiv, 61024, Ukraine 